\title{
ASSESSMENT OF THE BLACK SEA ECOSYSTEM POLLUTION WITH COPPER AND CADMIUM IN SELECTED BAYS OF SEVASTOPOL REGION
}

\author{
Marcin Niemiec', Barbara Wiśniowska-Kielian'1, Monika Arasimowicz', Natalya Kuzminowa² \\ 1 Department of Agricultural and Environmental Chemistry, University of Agriculture, A. Mickiewicza Ave. 21, \\ 31-120 Kraków, Poland, e-mail: niemiecm@tlen.pl, rrkielia@cyf-kr.edu.pl, komorowska.monika@interia.pl \\ 2 Institute of Biology of the Southern Seas of Ukrainian National Academy of Sciences, Sevastopol, Ukraine, \\ e-mail: kunast@rambler.ru
}

Received: 2015.09 .22

Accepted: 2015.10.06

Published: 2015.11.10

\begin{abstract}
A high level of anthropopressure has been registered in Sevastopol region, connected with its strategic role as the main city in the region, but also due to Russian Black Sea Fleet stationing there for many years. A significant source of the Black Sea contamination in Sevastopol area is the industry located in this city, municipal waste and agriculture. Implementing measures aimed at protection of the Black Sea and the evolution of their results requires monitoring conducted in the regions with various levels of anthropopressure. The work was aimed at the assessment of copper and cadmium content in water and algae in selected bays of the Black Sea in the vicinity of Sevastopol. Samples of water and algae were collected in August 2012 from eight Sevastopol bays (Galubaja, Kozacha, Kamyshova, Kruhla, Strieletska, Pishchana, Pivdenna and Sevastopolska) and from the open sea in the vicinity of Fiolent. Algae (Cystoseira barbata and Ulva rigida) were collected from the same places. Collected water was preserved on the sampling place and brought to the laboratory where its copper and cadmium concentrations were assessed. Collected algae were rinsed in distilled water, dried, then homogenised and mineralised. Copper and cadmium content were determined in the mineralizates using ASA method with electrothermal atomisation. Cadmium concentration in water ranged from 0.13 to $1.74 \mu \mathrm{g} \mathrm{Cd} \cdot \mathrm{dm}^{-3}$, and copper from 7.07 to $22.56 \mu \mathrm{g} \mathrm{Cd} \cdot \mathrm{dm}^{-3}$. Considerable differences in the content of the analysed elements were registered in individual bays. The highest content was assessed in Galubaja and Sevastopolska bays, whereas the lowest one in the water collected in the open sea and in Pivdenna bay. Copper concentrations in the analysed algae fluctuated from 3.375 to $14.96 \mathrm{mg} \mathrm{Cu} \cdot \mathrm{kg}^{-1}$ d.m. No differences were noted in this element content between the algae species. Cadmium content in the algae ranged from 0.133 to $1.133 \mathrm{mg} \mathrm{Cd} \cdot \mathrm{kg}^{-1} \mathrm{~d} . \mathrm{m}$. Higher accumulation of cadmium was observed in Cystoseira barbata than in Ulva rigida. The value of copper bioaccumulation coefficient (BC) ranged from 181 to 1201, whereas cadmium from 181 to 5256. The contents of the analysed metals, both in biotic and abiotic elements of the studied ecosystems point to anthropogenic enrichment and the results obtained for Sevastopolska, Galubaja and Kozacha bays indicate a hazardous, excessive bioaccumulation of copper and cadmium and to potential threat to the life of aquatic organisms and seafood consumers.
\end{abstract}

Keywords: the Black Sea, pollution, water, algae, copper, cadmium, monitoring, bioaccumulation.

\section{INTRODUCTION}

The Black Sea is the water reservoir with strategic importance in the scale of the region and the worldwide. Its importance results from its main city position in the region and from a many-year stationing of the former Soviet and later Russian Black Sea Fleet. Due to its location, trends of seaside areas development and the methods of management and disposal of both industrial and 
municipal wastes, mainly discharged into the sea without previous treatment, the coastal area of this reservoir is the place where the outcomes of such activities are noticeable very fast. The results are connected with increased amount of biogenic compounds, heavy metals and permanent organic compounds in the abiotic part of the ecosystem, which translates into a reduction of biodiversity and excessive accumulation of xenobiotics in living organisms, which negatively affect their life processes and pose hazard to people as their consumers [Caliceti et al. 2003, Chowdhury, Wood 2007, Das, Khangarot 2011]. Many substances which find their way to seawater reveal high toxicity and persist in the environment, therefore, measures aimed at protection of the environment do not bring immediate effects. Ukrainian regulations referring to the environment protection are rather restrictive, however, not fully observed due to economic reasons. Duties concerning environmental monitoring and their enforcement are distributed among ministries and their organizations [Strategic Action Plan... 2009]. Geographical location and quantitative and qualitative research of waters are necessary to understand the changes occuring in the Black Sea ecosystem and preserving biodiversity [Sundseth, Barova 2009]. In recent years the importance of the Black Sea in the policy of the European Union and Atlantic Treaty has been growing [Black sea synergy... 2007]. Over the last 50 years many changes have taken place in the land use in this region. The coastal zone becomes more and more polluted as a result of progressing intensification of agriculture, development of industry, marine transport and tourism [Langemad et al. 2009]. The Black Sea catchment is the area with considerable natural resources and advantageous strategic location between Central Asia, Europe and Near East. At the same time this region is facing numerous problems, such as "frozen" conflicts or problems with natural environment protection. Undertaking regional measures aimed at protection of the natural environment, energy, transport or safety may both prove beneficent for the welfare of the Black Sea countries' inhabitants and contribute to the welfare and political stability, therefore, to the improvement of safety [Black Sea synergy... 2007]. Countries of the region facing the difficulties need cooperation with international organizations [Langmead et al. 2009].

The presented investigations aimed at determining the level of pollution with copper and cadmium of selected elements of the Black Sea ecosystem in the Sevastopol region. Content of the studied elements in water and in algae from the green and brown algae genera were the parameters used for the accomplishment of the goal.

\section{MATERIALS AND METHODS}

In order to accomplish the assumed aim of investigations, water was sampled from 8 bays of Sevastopol and from the open sea in the vicinity of Fiolent in August 2012. The samples were collected from the surface water (the depth of $0-120$ $\mathrm{cm}$ ) by means of $200 \mathrm{~cm}^{3}$ probe. The collective sample, $3 \mathrm{dm}^{3}$ in volume, was composed of 15 primary samples, which were averaged. Mean laboratory sample was $500 \mathrm{~cm}^{3}$ in volume. The points of sample collection were chosen so as to make it possible to obtain a most representative sample for the whole bay. For this purpose, data on water movement and sea currents flows were used. The samples were collected from: Galubaja, Kozacha, Kamyshova, Kruhla, Strietelska, Pishchana, Pivdenna and Sevastopolska bays and from the open sea in the Fiolent vicinity (Figure 1).

Elements of biomonitoring were included in the research in order to better assess the state of anthropopressure. Samples of Cystoseira barbata and Ulva rigida were collected from the same places, because these species are common in the investigated area, and in the regions with similar conditions [Akcali, Kucuksezgin 2011]. After sampling, the water was preserved with $65 \%$ nitric acid used in the amount of $2 \mathrm{~cm}^{3}$ per each $100 \mathrm{~cm}^{3}$ of water, whereas the algae were rinsed in distilled water, dried at $65^{\circ} \mathrm{C}$ and homogenized. Samples prepared in this way were transported to the laboratory. Laboratory samples of algae were wet mineralized in a closed system using microwave energy. Analytical weight was c.a. $0.5 \mathrm{~g}$ in conversion to dry mass. The material was dissolved in $\mathrm{HNO}_{3}$ and $\mathrm{H}_{2} \mathrm{O}_{2}$ mixture, in 5:1 ratio $(v / v)$. Copper concentration was assessed by atomic absorption spectrometry with electrothermal atomization in M6 Thermo apparatus, at the wave length $342.8 \mathrm{~nm}$. Copper detection limit in the applied measurement was $0.054 \mu \mathrm{g} \cdot \mathrm{dm}^{-3}$. Measurement uncertainty of the applied method was $\pm 6 \%$. The method limit of detection was 2.70 $\mu \mathrm{g} \mathrm{Cu} \cdot \mathrm{dm}^{-3} \mathrm{~d}$.m. of the biological material and $0.06 \mu \mathrm{g} \mathrm{Cu} \cdot \mathrm{dm}^{-3}$ of water. Cadmium concentration in the obtained solutions was assessed using 


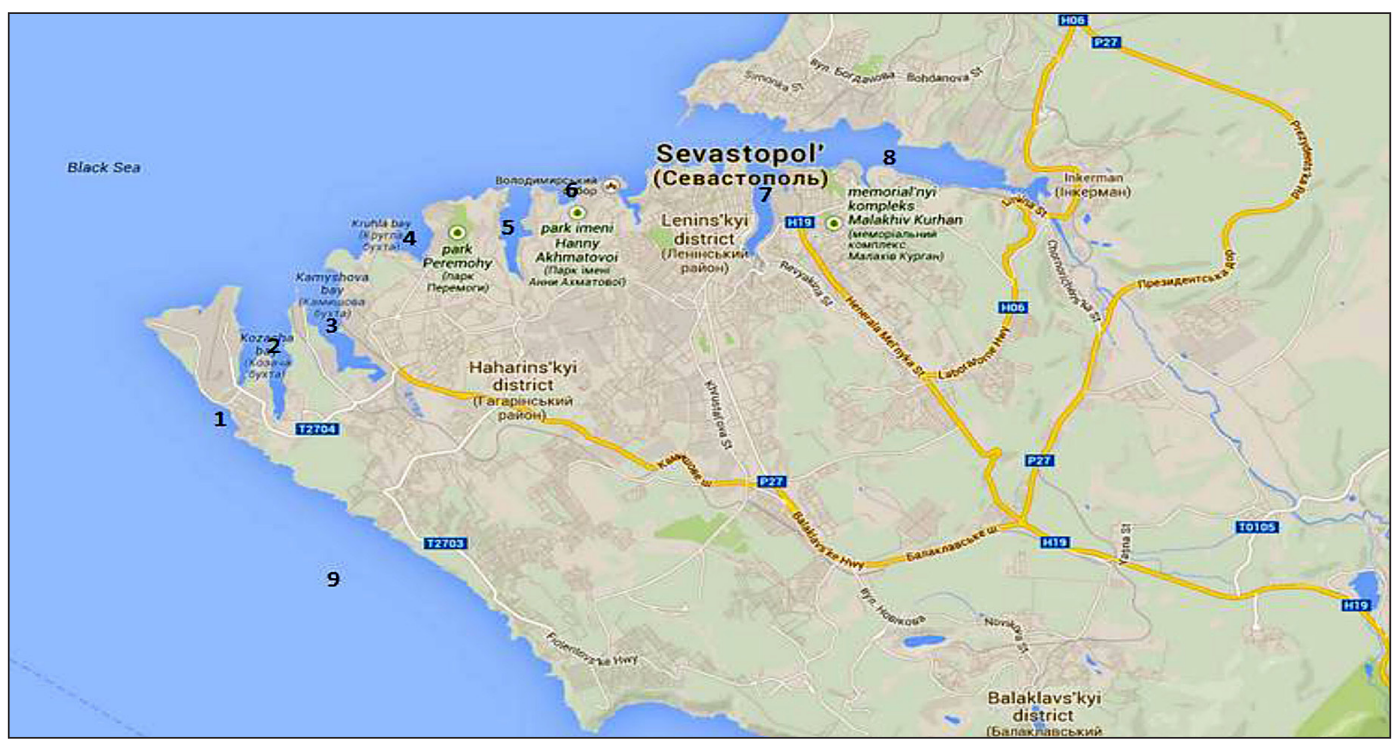

Figure 1. Points of sampling (1-9)

atomic absorption spectrometry with electrothermal atomization at M6 Thermo apparatus, at the wavelength of $228.8 \mathrm{~nm}$. Cadmium limit of detection of the applied measurement method was $0.027 \mu \mathrm{g} \cdot \mathrm{dm}^{-3}$. Uncertainty of measurement in the applied method was $\pm 9 \%$. Detection limit of the method was $1.35 \mu \mathrm{g} \mathrm{Cd} \cdot \mathrm{dm}^{-3} \mathrm{~d}$.m. of the biological material and $0.03 \mu \mathrm{g} \mathrm{Cd} \cdot \mathrm{dm}^{-3}$ of water. The correctness of analyses of the studied elements was verified using a certified reference material CRM 16-050.

The assessed contents of metals were used to compute the values of bioaccumulation coefficients as a ratio of metal content in algae to its concentration in water.

\section{RESULTS AND DISCUSSION}

Copper is a microelement crucial for living organisms' development. In sea algae organisms it participates in electron transport during the photosynthesis process and in many enzymatic transformations. However, if it occurs in excess, it becomes very toxic. Among the elements common in the environment, copper is the second after mercury most toxic element for sea algae [Gledhill et al. 1997]. Its excess in the environment causes inhibition of photosynthesis process, decline in the pigment content, which directly or indirectly translates into growth inhibition. Optimum copper concentration in water immediately available to sea algae ranges from 0.063 to 6.3 $\mu \mathrm{g} \cdot \mathrm{dm}^{-3}$ [Gledhill et al. 1997]. However, the share of copper available to these organisms may con- stitute from several to over forty percent of this element total content in water.

Copper content in water sampled from individual bays of Sevastopol ranged from 7.07 to $22.56 \mu \mathrm{g} \mathrm{Cu} \cdot \mathrm{dm}^{-3}$ (Figure 2), and the mean content was $14.7 \mu \mathrm{g} \mathrm{Cu} \cdot \mathrm{dm}^{-3}$.

The lowest copper concentrations were assessed in water collected in the open sea and in Pivdenna and Kruhla Bays. Copper contents in these samples were on the level of 7-8 $\mu \mathrm{g} \mathrm{Cu} \cdot \mathrm{dm}^{-3}$. The other water samples contained about $2-3$ fold less of copper, while the highest concentrations were assessed in water from Kozacha and Sevastopolska Bays.

Copper is the element which occurs in the natural environment in small quantities. Due to a common use of copper by man, its elevated contents are always registered in the areas of strong anthropopressure. The source of this element is industry, agriculture, activities of human life, but also transport and fuel burning.

Copper is one of the most toxic metals for aquatic organisms. Considering its toxicity, it poses third (after mercury and silver) among the metals commonly present in the environment [Sanhita, Khangarot 2011]. In the world ecosystems negative results of elevated copper concentrations are rare because of strong affinity of this element to organic matter.

Kahle and Zauke [2003] stated cooper concentrations in water of the Arctic Sea between 0.1 and $0.2 \mu \mathrm{g} \mathrm{Cu} \cdot \mathrm{dm}^{-3}$, which may be regarded as a natural level in seawater. Copper content in fresh water from the unpolluted areas usually fluctuated from 1 to $2 \mu \mathrm{g} \mathrm{Cu} \cdot \mathrm{dm}^{-3}$ [Kabata-Pendias, 


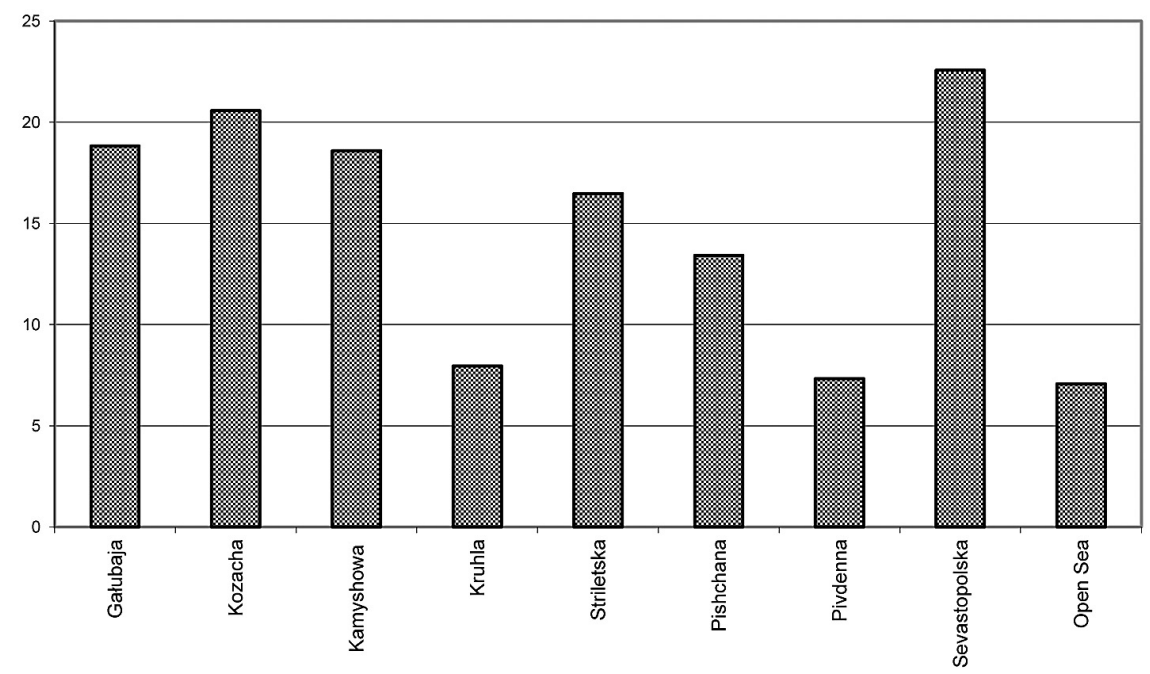

Figure 2. Content of copper in water $\left[\mu \mathrm{g} \mathrm{Cu} \cdot \mathrm{dm}^{-3}\right]$

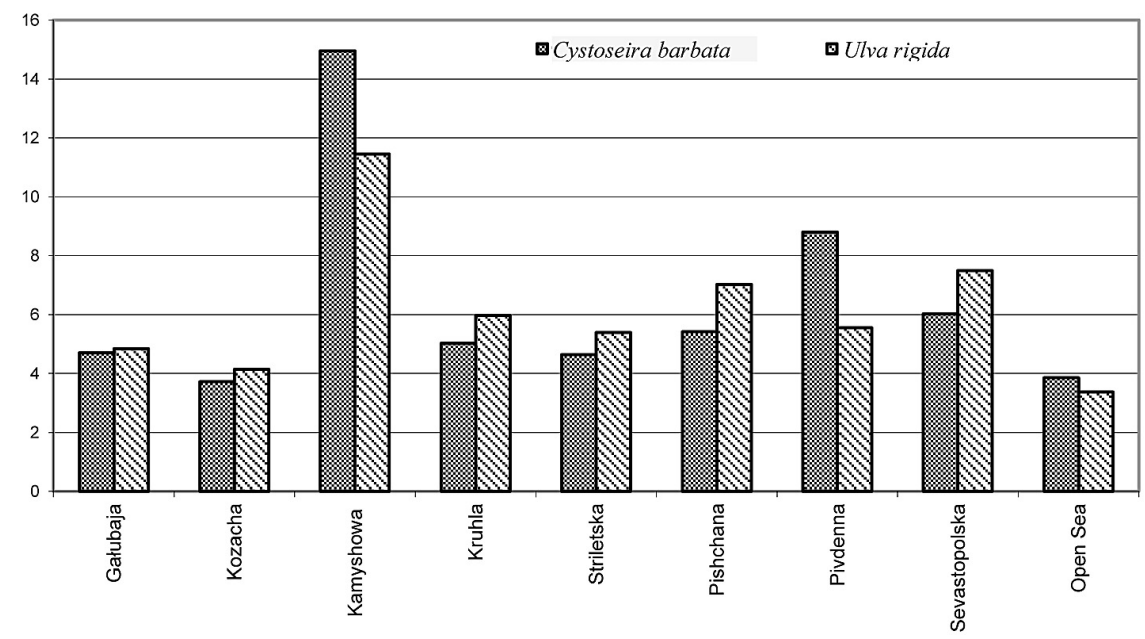

Figure 3. Content of copper in macroalgae $\left[\mathrm{mg} \mathrm{Cu} \cdot \mathrm{kg}^{-1}\right]$

Pendias 1999]. In sea ecosystems, generally lower copper concentrations in water are registered. However, the total content of trace elements in water says little about the hazard they pose to living organisms, because the number of their bioavailable forms depends not only on the contents in the biotope, but on their chemical forms and physicochemical properties of water. Copper bioavailability in sea environment is always greater due to the specificity of physiological processes in aquatic organisms connected with osmoregulation. High water temperature causes increase in copper toxicity, which is connected with diminishing oxygen content in water, which results in increased concentration of copper compounds dissolved in water, but also limited ability of living organisms to detoxificatin [Richards, Chaloupka 2009]. On the other hand, increased water salinity limits copper bioavailability [Mamboya et al. 2009]. Therefore, the assessment of hazard posed to aquatic ecosystem in connection with trace element pollution should base on the use of living organisms as bioindicators. Bioaccumulation of trace elements in living organisms is determined by two processes. The first relies on reducing this element's absorption from the environment, whereas the second is associated with its excretion from the organism. Depending on the organism strategy, one of these processes is more intensive and protects the organism against poisoning [Richards, Chaloupka 2009]. In order to obtain reliable information about the state of the environment on the basis of biomonitoring research, one should use organisms which reveal the ability to accumulate pollutants at limited effect of these substances on their growth and development.

Algae are organisms commonly used as bioindicators of the natural environment pollution with trace elements. Due to their common oc- 
currence, high ability for accumulation of trace elements, high resistance to their increased concentrations in the environment and being easily obtainable material for analyses, algae are regarded as good bio-indicators of sea environment pollution with heavy metals [Huerta-Diaz et al. 2007, Mamboya et al. 2009, Brito et al. 2012, Horta-Puga et al. 2013], for example, algae from the Ulva genus [Boubonari et al. 2008]. However, it is important to choose appropriate algae species later used for biomonitoring. One of the more important environmental factors which may limit the growth and development of macroalgae is water salinization. Macroalgae, of Padina genus, reveal high abilities for trace element accumulation, but they are sensitive to changes in salinization, which, to a great extent, limits their possible applications [Lou, Liu 2011, Chakrabort et al. 2014]. It is particularly important in the zones of strong river water mixing with seawater, especially in the areas with great seasonal fluctuations of river water flow. The use of algae as bioindicators of sea environment pollution has also other important practical aspect. High affinity of macroalagae to heavy metals may be a factor limiting their use for consumption. About 6 million tons of algae fresh mass is used annually for consumption and by industries. However, many authors point to a hazard of excessive accumulation of trace elements in aquaculture and seafood products, despite the fact that they are produced in the areas of limited anthropopressure and low concentrations of trace elements in biotope [Besala et al. 2009, Naser 2013].

Copper content in Cystoseira barbata ranged from 3.725 to $14.95 \mathrm{mg} \cdot \mathrm{kg}^{-1} \mathrm{~d}$.m. The highest content of this element were noted in algae obtained in Kamyshova Bay and by $69 \%$ lower in Pivdenna Bay, where respectively 14.95 and $8.80 \mathrm{mg}$ $\mathrm{Cu} \cdot \mathrm{kg}^{-1} \mathrm{~d} . \mathrm{m}$. were registered. In algae collected in other bays, copper concentrations were between 1.5-4.5 times lower, fluctuating from 3.375 to $6.025 \mathrm{mg} \mathrm{Cu} \cdot \mathrm{kg}^{-1} \mathrm{~d}$. $\mathrm{m}$ with the difference between them reaching $78.5 \%$. Copper content in Cystoseira barbata taken from the open sea was $3.858 \mathrm{mg}$ $\mathrm{Cu} \cdot \mathrm{kg}^{-1}$ d.m. This element content in Ulva rigida algae differed slightly from the value registered in Cystoseira barbata and ranged from 3.375 to $11.45 \mathrm{mg} \mathrm{Cu} \cdot \mathrm{kg}^{-1}$ d.m., but higher quantities of copper were found in algae from most of the bays (Figure 3). The greatest amounts of copper were noted in Ulva rigida from Kamyshova Bay, then from Sevastopolska and Pishchana, whereas the least amount in algae taken in the open sea and in Kozacha Bay. Strezov and Nonova [2009] stated copper contents in Ulva rigida and Cystoseira barbata, collected in Bulgarian coastal zone of the Black Sea, similar to registered in the Author's own studies in algae from the bays of Sevastopol, however, much higher contents than in the same organisms collected in the open sea.

The obtained results are approximate to those registered by Brito et al. [2012] in various algae species from the area with strongly intensified anthropopressure in Brazil. Horta-Puga et al. [2013] stated lower copper concentrations, ranging from 2.3 to $2.9 \mathrm{mg} \mathrm{Cu} \cdot \mathrm{kg}^{-1} \mathrm{~d}$.m. in various algae species collected from the vicinity of Veracruz coral reef in Mexico. On the other hand, Wallenstein et al. [2009] noted between 1.18 and about $6 \mathrm{mg} \mathrm{Cu} \cdot \mathrm{kg}^{-1} \mathrm{~d}$.m. in various algae species from the vicinity of the Azores islands collected on sites with diversified level of anthropopressure. At the same time they demonstrated the effect of rainy season and connected with it greater deposition of pollutants in the region on the trace element content in the algae.

The authors call attention to the sensitivity of the environment pollution assessment method using algae. On the other hand, Rodriguez-Figueroa et al. [2009] registered values exceeding even 100 $\mathrm{mg} \mathrm{Cu} \cdot \mathrm{kg}^{-1} \mathrm{~d}$.m. in algae from the Gulf of Mexico in the region of copper mines influence at very high fluctuations of the content dependent on the sampling point. In the Author's own research, in all bays, except Kozacha Bay, a greater copper accumulation was observed in both algae species in comparison with its contents in the algae collected in the open sea.

Waters of the bays and coastal zones are usually more polluted in comparison with the open sea area because of their limited mixing and greater pollutant inflow [Gao, Chen 2012]. Ulva rigida algae are characterized by a very fast growth under favourable environmental conditions. The growth of these organisms and their uptake of trace elements are in the first place affected by the environmental conditions, such as water temperature or the amount of light but primarily by the salinization [Besda et al. 2009]. Under favourable condition the algae may quickly produce large amounts of biomass causing dilution of elements in tissues.

Values of copper bioaccumulation coefficient in Cystoseira barbata from the individual bays in Sevastopol region fluctuated from 181 to 1202 (Table 1). 
Table 1. Values of bioaccumulation coefficent of copper and cadmium in studied ecosystem

\begin{tabular}{|l|c|c|c|c|}
\hline \multirow{2}{*}{ Points of sampling } & \multicolumn{3}{|c|}{ Bioaccumulation coefficent } \\
\cline { 2 - 5 } & \multicolumn{2}{|c|}{ Cu } & \multicolumn{2}{c|}{ Cystoseira barbata } \\
\cline { 2 - 5 } & Cystoseira barbata & Ulva rigida & 833 & 208 \\
\hline Gałubaja Bay & 250 & 257 & 753 & 181 \\
\hline Kozacha Bay & 181 & 201 & 1303 & 394 \\
\hline Kamyshowa Bay & 804 & 616 & 2120 & 598 \\
\hline Kruhla Bay & 633 & 752 & 1667 & 456 \\
\hline Striletska Bay & 281 & 328 & 986 & 2821 \\
\hline Pishchana Bay & 404 & 523 & 5256 & 431 \\
\hline Pivdenna Bay & 1201 & 758 & 651 & 381 \\
\hline Sevastopolska Bay & 267 & 332 & 1714 & 476 \\
\hline Open Sea & 546 & 477 & & \\
\hline
\end{tabular}

Small differences of this parameter were noticed in Ulva rigida algae collected in the individual bays in relation to Cystoseira barbata, but the range of this coefficient value was lower, i.e. from 201 to 759. Copper bioaccumulation coefficient reached the highest values for both algae species collected in Pivdenna Bay. High values of this coefficient in this sampling point resulted from low copper concentration in water. Copper content in both algae species collected in this bay points to considerable anthropogenic enrichment. In both species copper bioaccumulation coefficient reached the lowest values in the algae from Kozacha Bay. Low values of copper bioaccumulation coefficient were assessed also in the studied algae from Galubaja, Sevastopolska and Strieletska Bays, where low values of this parameter resulted from high copper concentration in the water.

Much higher values of copper bioaccumulation coefficient in Cystoseira barbata and Ulva rigida than those obtained in the author's own research, i.e. within the range of 1151-16162 were noted in various regions of the Aegean Sea [Akcali, Kucuksezgin 2001]. Such big differences in this parameter value result from a considerable diversification of copper concentrations in water. Melville and Pułkownik [2007] report very high values of copper bioaccumulation coefficients, within the range from about 5000 to 80000 , in algae taken from several estuaries of the western Australia. The authors registered a great diversification of copper content in algae at small differences in this element water concentration in the individual estuaries.

Natural cadmium contents in fresh water do not exceed $0.02 \mu \mathrm{g} \mathrm{Cd} \cdot \mathrm{dm}^{-3}$ [Bandara et al. 2010].
This element concentration in seawater is much lower, however, due to the specificity of sea organisms metabolism, considerable cadmium concentrations are usually assessed in sea animals which live in unpolluted environment. This element content in the analyzed water fluctuated from 0.13 to $1.74 \mu \mathrm{g} \mathrm{Cd} \cdot \mathrm{dm}^{-3}$ (Figure 4), on average $0.69 \mu \mathrm{g} \mathrm{Cd} \cdot \mathrm{dm}^{-3}$.

The biggest quantities of this element were assessed in waters collected from Sevastopolska Bay, and then from Galubaja Bay. The least amount of cadmium was found in water taken from Pivdenna Bay, whereas in water from the open sea its concentration was over 2.5 -fold higher. Cadmium concentrations registered in all samples indicate anthropogenic enrichment of the ecosystem in this element.

Average cadmium concentration in the coastal waters of Denmark was $0.025 \mu \mathrm{g} \mathrm{Cd} \cdot \mathrm{dm}^{-3}$ [Bjerregaard et al. 2005]. Waters of Gioronde estuary in France contained much less of this element than assessed in the author's own investigations, i.e. between 0.03 and $0.207 \mu \mathrm{g} \mathrm{Cd} \cdot \mathrm{dm}^{-3}$. At such cadmium concentrations, a high and exceeding the norm allowable for food products, accumulation of this element was determined in aquaculture animals [Boutier et al. 2000], therefore, it is necessary to monitor the quantity of cadmium entering human food chain through the organisms originating from the aquaculture.

Cadmium concentrations registered in the author's own research may be dangerous both for sea organisms and seafood consumers. This element content in Cystoseira barbata fluctuated from 0.483 to $1.133 \mathrm{mg} \mathrm{Cd} \cdot \mathrm{kg}^{-1} \mathrm{~d} . \mathrm{m}$. (Figure 5) and was on average $0.769 \mathrm{mg} \mathrm{Cd} \cdot \mathrm{kg}^{-1} \mathrm{~d} . \mathrm{m}$. The biggest amounts of this element were determined 


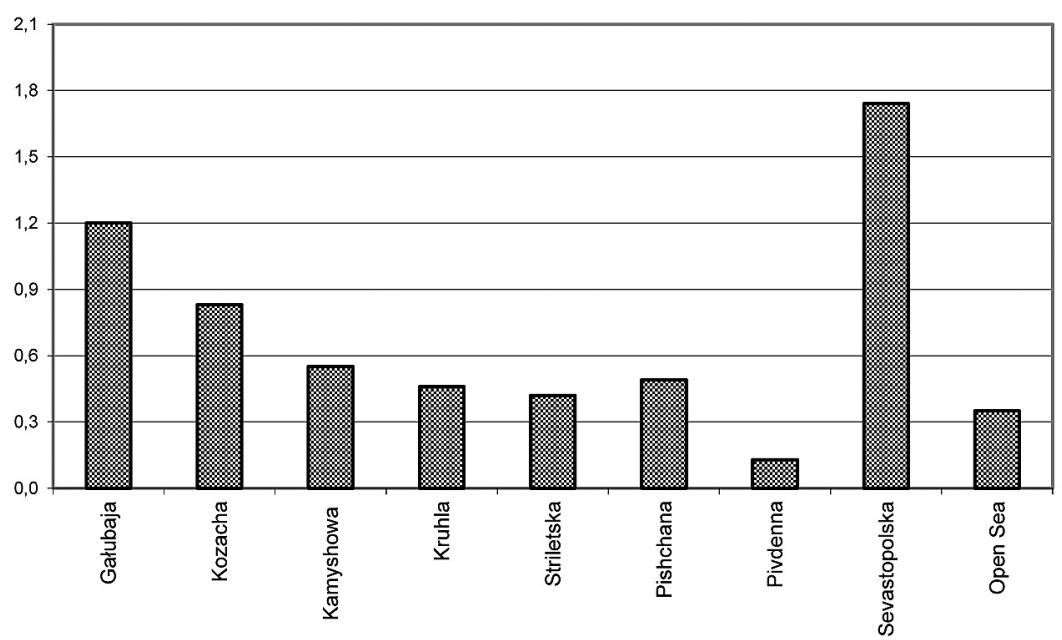

Figure 4. Content of cadmium in water $\left[\mu \mathrm{g} \mathrm{Cd} \cdot \mathrm{dm}^{-3}\right]$

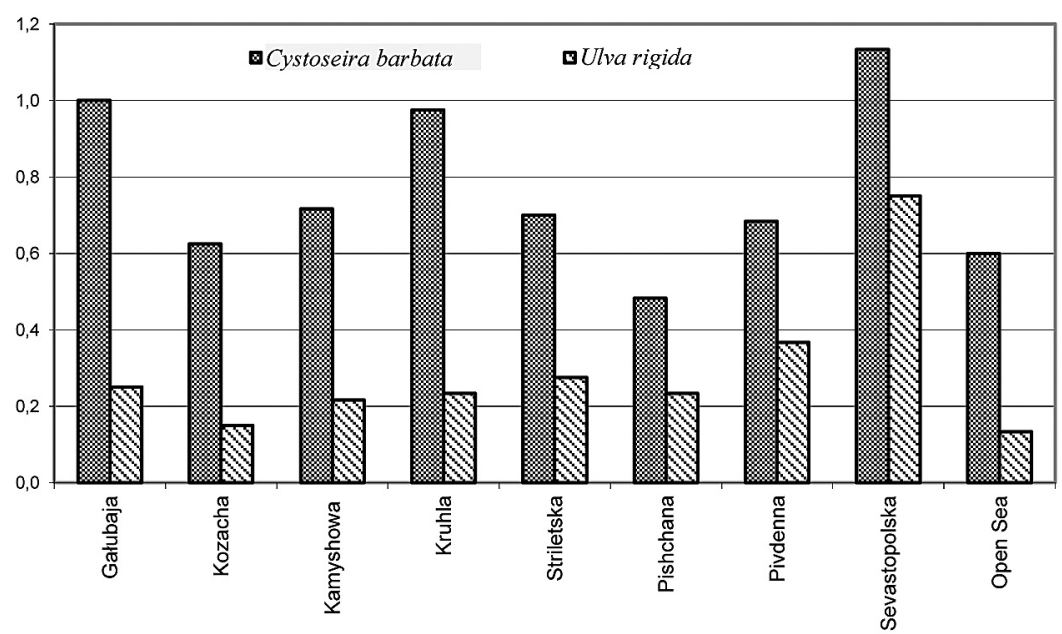

Figure 5. Content of cadmium in macroalgae $\left[\mathrm{mg} \mathrm{Cd} \cdot \mathrm{kg}^{-1}\right]$

in Cystoseira barbata algae taken in Sevastopolska Bay, and then from Galubaja and Kruhla Bays, respectively $1.133,1.000$ and $0.975 \mathrm{mg} \mathrm{Cd} \cdot \mathrm{kg}^{-1}$ d.m. Algae collected in Pishchana Bay and from the open sea contained the lowest quantities of cadmium, 0.483 and $0.600 \mathrm{mg} \cdot \mathrm{kg}^{-1} \mathrm{~d} . \mathrm{m}$., respectively. Average cadmium content in Ulva rigida algae collected in all sampling points was over 2.5 times higher than assessed in Cystoseira barbata, i.e. $0.290 \mathrm{mg} \cdot \mathrm{kg}^{-1} \mathrm{~d}$.m. This element content in samples from individual points fluctuated from 0.133 to $0.750 \mathrm{mg} \mathrm{Cd} \cdot \mathrm{kg}^{-1} \mathrm{~d}$.m. (Figure 5). Algae of this species collected from Sevastopolska Bay contained the greatest amounts of cadmium, $0.750 \mathrm{mg} \cdot \mathrm{kg}^{-1} \mathrm{~d}$.m., whereas those collected in other bays had between 2 and 5 times less cadmium. The least of cadmium was found in Ulva rigida algae collected in the open sea and in Kozacha Bay.

Cadmium contents in Ulva rigida algae collected in various regions of the Aegean Sea were much lower than those assessed in the author's own research and fluctuated from 0.014 to 0.056 $\mathrm{mg} \cdot \mathrm{kg}^{-1}$ d.m. [Akcali, Kucuksezgin 2011]. The authors also noted higher accumulation of this element in Cystoseira barbata than in Ulva rigi$d a$ algae. On the other hand, Strezov and Nonova [2009] registered higher content of cadmium in Ulva rigida in comparison with Cystoseira barbata. The level of this metal accumulation in algae collected in Bulgarian coastal zone of the Black Sea was similar to registered in the asuthor's own investigations in algae from Sevastopol bays, but much higher than in algae from the open sea. Horta-Puga et al. [2013] reported much lower than obtained in the author's own studies cadmium contents in algae collected from Veracruz Coral Reef. On the other hand, Brito et al. [2012] found approximate cadmium contents in various algae species from Todos os Santos Bay, whereas Wallenstein et al. [2009] in algae from the Azores region. Cadmium contents 
in algae assessed in the author's own research are comparable with those presented by Denton et al. [2009] in algae collected from polluted area of the Marianas. Rodriguez-Figueroa et al. [2009] reported much higher cadmium content in Padina durvillaei algae from the region under the influence of copper mine in the coastal zone of Santa Rozalia than presented in the author's own studies.

Values of cadmium bioaccumulation coefficients in the studied algae ranged widely, from 181 to 5254 (Table 1). The highest values of bioaccumulation coefficient were registered for both algae species collected in Pivdenna Bay: 5243 for Cystoseira barbata and 2823 for Ulva rigida. High values of bioaccumulation coefficient in this bay resulted from low cadmium concentration in water. For Cystoseira barbata algae values of bioaccumulation coefficient from the other bays were between 2.5 and 8 times lower and from 4 to 14.5 times lower for Ulva rigida. The lowest value of bioaccumulation coefficient was noted in Cystoseira barbata collected in Sevastopolska Bay, and for Ulva rigida in Kozacha Bay, 651 and 181, respectively. In the research conducted by Akcali and Kucuksezgin [2011], cadmium bioaccumulation coefficient in the studied algae from various places of the Aegean Sea assumed values within a narrower range than in the author's own investigations, i.e. from 40 to 896 , depending on this element content in water.

\section{CONCLUSIONS}

1. Copper and cadmium contents in water collected from individual bays and open sea in the region of Sevastopol revealed considerable diversification, pointing to anthropogenic enrichment.

2. Copper and cadmium concentrations in Cystoseira barbata and Ulva rigida greatly differed, depending on the sampling point, which evidences a diversified level of anthropopressure and limited ability for water mixing.

3. Generally, both water and algae collected in all bays contained greater quantities of copper and cadmium in comparison with the samples collected in the open sea.

4. The contents of the studied elements in algae are approximate to assessed in polluted areas.

\section{Acknowledgements}

The research results carried out within the subject No. 3101 were financed from the subsidy for science granted by the Polish Ministry of Science and Higher Education.

\section{REFERENCES}

1. Black Sea synergy - a new regional cooperation initiative. Commision of the European Communities, Brussels. 11-04-2007 Com (2007) 160, 13 pp.

2. Boubonari T., Malea P., Kevrekidis T. 2008. The green seaweed Ulva rigida as a bioindicator of metals ( $\mathrm{Zn}, \mathrm{Zu}, \mathrm{Pb}$ and $\mathrm{Cd}$ ) in a low-salinity coastal environment. Botanica Marina, 51(6), 472-484.

3. Chowdhury M.J., Wood C.M. 2007. Renal function in the freshwater rainbow trout after dietary cadmium acclimation and waterborne cadmium challenge. Comp. Biochem. Physiol. C, 145(3), 321-332. doi:10.1016/j.cbpc.2007.01.004.

4. Richards R.G., Chaloupka M. 2009. Temperaturedependent bioaccumulation of copper in an estuarine oyster. Sci. Total Environ., 407(22), 59015906. doi:10.1016/j.scitotenv.2009.07.039.

5. Das S., Khangarot B.S. 2011. Bioaccumulation of copper and toxic effects on feeding, growth, fecundity and development of pond snail Lymnaealuteola L. J. Hazard. Mater., 185(1), 295-305. doi:10.1016/j.jhazmat.2010.09.033.

6. Kahle J., Zauke G-P. 2003. Bioaccumulation of trace metals in the Antarctic amphipod Orchomene plebs: evaluation of toxicokinetic models. Mar. Environ. Res., 55(5), 359-384. doi:10.1016/S01411136(02)00288-X.

7. Kabata-Pendias A., Pendias H. 1999. Biogeochemia pierwiastków śladowych. Wyd. PWN, Warszawa, 352 pp.

8. Bandara J.M.R.S., Wijewardena H.V.P., Seneviratne H.M.M.S. 2010. Remediation of cadmium contaminated irrigation and drinking water: A large scale approach. Toxicol. Lett., 198(1), 89-92. doi:10.1016/j.toxlet.2010.04.030.

9. Bjerregaard P., Bjørn L., Nørum U., Pedersen K.L.. 2005. Cadmium in the shore crab Carcinusmaenas: seasonal variation in cadmium content and uptake and elimination of cadmium after administration via food. Aquat. Toxicol., 72(1-2), 5-15. doi:10.1016/j.aquatox.2004.11.018.

10. Boutier B., Chiffoleau J-F., Gonzalez J-L., Lazure P., Auger D., Truquet I. 2000. Influence of the Gironde estuary outputs on cadmium concentrations in the coastal waters: consequences on the Marennes-Oléron bay (France). Oceanol. Acta, 23, 745-757. doi:10.1016/S0399-1784(00)01119-1. 
11. Sundseth K., Barova S. 2009. Natura 2000 in the Black Sea Region. Office for Official Publications of the European Communities, Luxembourg, pp. 12.

12. Mamboya F, Lyimo T.J., Landberg T., Björk M. 2009. Influence of combined changes in salinity and copper modulation on growth and copper uptake in the tropical green macroalga Ulva reticulate. Estuar. Coast. Shelf Sci., 84(3), 326-330. doi:10.1016/j.ecss.2009.03.034.

13. Luo M.B., Liu F. 2011. Salinity-induced oxidative stress and regulation of antioxidant defense system in the marine macroalga Ulva prolifera. J. Experimental Marine Biology and Ecology, 409(1-2), 223-228. doi:10.1016/j.jembe.2011.08.023.

14. Gledhill M., Nimmo M., Hill S.J., Brown M.T. 1997. The toxicity of copper(II) species to marine algae, with particular reference to macroalgae. J. Phycol., 33, 2-11, doi:10.1111/j.00223646.1997.00002.x

15. Besada V., Andrade J.M., Schultze F., González J.J. 2009. Heavy metals in edible seaweeds commercialised for human consumption. J. Marine Systems. 75(1-2), 305-313, doi:10.1016/j.jmarsys.2008.10.010.

16. Huerta-Diaz M.A., de León-Chavira F., Lares M.L., Chee-Barragán A., Siqueiros-Valencia A. 2007. Iron, manganese and trace metal concentrations in seaweeds from the central west coast of the Gulf of California. Applied Geochemistry, 22(7), 13801392. doi:10.1016/j.apgeochem.2007.03.052.

17. Akcali I., Kucuksezgin F. 2011. A biomonitoring study: Heavy metals in macroalgae from eastern Aegean coastal areas. Mar. Pollut. Bull., 62(3), 637-645, doi:10.1016/j.marpolbul.2010.12.021.

18. Melville F., Pulkownik A. 2007. Investigation of mangrove macroalgae as biomonitors of estuarine metal contamination. Sci. Total Environ. 387(1-3), 301-309, doi:10.1016/j.scitotenv.2007.06.036.

19. Brito G.B., de Souza T.L., Bressy F.C., Moura C.W.N., Korn M.G.A. 2012. Levels and spatial distribution of trace elements in macroalgae species from the Todosos Santos Bay, Bahia, Brazil. Mar. Pollut. Bull., 64(10), 2238-2244, doi:10.1016/j. marpolbul.2012.06.022.

20. Horta-Puga G., Cházaro-Olvera S., Winfield I., Avila-Romero M., Moreno-Ramírez M. 2013. Cadmium, copper and lead in macroalgae from the Veracruz Reef System, Gulf of Mexico: Spatial distribution and rainy season variability. Mar. Pollut. Bull., 68(1-2), 127-133, doi:10.1016/j.marpolbul.2012.12.008.

21. Caliceti M., Argese E., Sfriso A., Pavoni B. 2002. Heavy metal contamination in the seaweeds of the
Venice lagoon. Chemosphere, 47(4), 443-454, doi:10.1016/S0045-6535(01)00292-2.

22. Strezov A., Nonova T. 2009. Influence of macroalgal diversity on accumulation of radionuclides and heavy metals in Bulgarian Black Sea ecosystems. J. Environ. Radioactiv., 100(2), 144-150, doi:10.1016/j.jenvrad.2008.09.007

23. Wallenstein F.M., Couto R.P., Amaral A.S., Wilkinson M., Neto A.I., Rodrigues A.S. 2009. Baseline metal concentrations in marine algae from São Miguel (Azores) under different ecological conditions - Urban proximity and shallow water hydrothermal activity. Mar. Pollut. Bull., 58(3), 438-443, doi:10.1016/j.marpolbul.2008.11.021.

24. Denton G.R.W., Morrison R.J., Bearden B.G., Houk P., Starmer J.A., Wood H.R. 2009. Impact of a coastal dump in a tropical lagoon on trace metal concentrations in surrounding marine biota: A case study from Saipan, Commonwealth of the Northern Mariana Islands (CNMI). Mar. Pollut. Bull., 58(3), 424-431, doi:10.1016/j.marpolbul.2008.11.029.

25. Strategic Action Plan for the Environmental Protection and Rehabilitation of the Black Sea Adopted in Sofia, Bulgaria, 17 April 2009. The Commission on the Protection of the Black Sea Against Pollution.

26. Langmead O., McQuatters-Gollop A., Mee L.D., Friedrich J., Gilbert A.J., Gomoiu M-T., Jackson E.L., Knudsen S., Minicheva G., Todorova V. 2009. Recovery or decline of the Northwestern Black Sea: A societal choice revealed by socio-ecological modeling. Ecol. Modell., 220(21), 2927-2939, doi:10.1016/j.ecolmodel.2008.09.011.

27. Chakraborty S., Bhattacharya T., Singh G., Maity J.P. 2014. Benthic macroalgae as biological indicators of heavy metal pollution in the marine environments: A biomonitoring approach for pollution assessment. Ecotoxicol. Environ. Saf., 100, 61-68, doi:10.1016/j.ecoenv.2013.12.003.

28. Gao X., Chen C-T.A. 2012. Heavy metal pollution status in surface sediments of the coastal Bohai Bay. Water Res., 46(6), 1901-1911, doi:10.1016/j. watres.2012.01.007.

29. Naser H.A. 2013 Assessment and management of heavy metal pollution in the marine environment of the Arabian Gulf: A review. Mar. Pollut. Bull., 72(1), 6-13, doi:10.1016/j.marpolbul.2013.04.030.

30. Rodríguez-Figueroa G.M., Shumilin E., SánchezRodríguez I. 2009. Heavy metal pollution monitoring using the brown seaweed Padinadurvillaei in the coastal zone of the Santa Rosalía mining region, Baja California Peninsula, Mexico. J.Appl. Phycol., 21(1), 19-26, doi:10.1007/s/10811-008-9346-0. 